\title{
LCA of alternative granular materials - Assessment of ecotoxicity and toxicty for road case studies
}

\author{
A. Jullien ${ }^{\mathrm{a}, \Uparrow}$, C. Proust ${ }^{\mathrm{b}}$, O. Yazoghli-Marzouk ${ }^{\mathrm{c}}$ \\ ${ }^{a}$ IFSTTAR, allée des ponts et chaussées cs4 F-44344 Bouguenais cedex, France \\ ${ }^{\mathrm{b}}$ Université d'Orléans, 8 rue Leonard de Vinci F-45 071 Orléans cedex 2, France \\ ${ }^{\mathrm{c}}$ CEREMA, Direction Départementale Centre-Est, Département Laboratoire Autun, BP 141 - Boulevard Bernard Giberstein, 71404 Autun, France
}

highlights

Impacts assessment of roads alternative materials with a mid-point model (EP, TP).

Determination of a wide impact range between several materials.

Allocation of all the leaching impacts to any alternative materials.

Application of any leaching data obtained from various international standards.

Keywords:

LCA

Alternative materials

Ecotoxicity

Toxicity

Impacts

Road abstract

This paper assesses alternative granular material use as regards ecotoxicity and toxicity. Stockpiling and use in various roads are considered. Leachates datasets of materials and field tests are collected from lit-erature, the study is focused on MSWI BA, RAP and FS. LCIs due to leaching and percolation are built. Corresponding impacts were determined using a mid-point method: the EP TP results exhibit significant differences between the resources in favour of including such impact to LCA for recycling assessment. A model to allocate all the leaching potential to the alternative resource is proposed and discussed for bet-ter assessment within LCA framework.

\section{Introduction}

The continuous increase of industrial waste production still requires strategies to reuse and recycle these materials since their storage by landfilling is limited by a decreasing availability of space and increasing of cost disposal. The last two decades have shown a growing interest in the use of alternative materials within the area of road construction, deriving from the wish to spare natural resources as well as to reduce landfills [1-5]. Laws, and directives as well as guidelines and methods were published to support the development of this industry, in different countries [6,7], establish-ing a legal framework for alternative materials recycling in road. Generally, the prescriptions are based on intrinsic geotechnical and environmental properties of the alternative materials. When

\footnotetext{
$\Uparrow$ Corresponding author.

E-mail addresses: agnes.jullien@ifsttar.fr (A.Jullien), bchantal.proust@ univ-orleans.fr (C. Proust), cOumaya.Marzouk@ @erema.fr (O. Yazoghli-Marzouk).
}

road projects' stakeholders are interested in the use of these mate-rials, they may need a global evaluation not only on the road con-struction but also for use phase, maintenance and end-of-life. Therefore, the assessment of the effects on the environment of road infrastructures need operational tools along the whole life cycle. Several Life Cycle Assessment (LCA) tools exist at the international level [8-10], as LCA is the commonly used global assessment methodology. LCA requires both the identification of relevant and reliable indicators for impact assessment applicable to a project, a process, a product, from its cradle-raw material extraction to its end-of-life or grave-disposal $[11,12]$.

LCA allows the comparison of the effects on environment of var-ious alternative resources for road projects, which is valuable for circular economy only if taking into account the corresponding impacts.

Actually, the use phase in roads LCA tools is assessed consider-ing traffic impacts. The impacts of alternative materials during stockpiling and use under traffic conditions, when submitted to 
rainfall are not considered. As regards alternative materials, rain-water may leach chemicals substances such as heavy metals, met-alloids, polycyclic aromatic hydrocarbons and salts, either during handling and stockpiling $[13,14]$, or due to infiltration through the pavement surface containing recycled materials [15-18]. All these pollutants contribute to different environmental impacts. Thus, even if the alternative material fits with guidelines and regulatory limits and is suitable to be used as road material, it leaches chemical substances to water and has an impact on the surround-ing environment. For comparisons between materials, any LCA should take into account such impacts, which needs to build LCI related with release to water during the material life cycle.

The present study aims at quantifying the release to water, the corresponding LCIs and the materials impacts considering their use in different road layers. The alternative materials investigated in this study for that purpose are therefore municipal solid waste incinerator (MSWI BA), milled recycled asphalt pavement (RAP) and foundry sand (FS).

A general approach to build alternative materials LCI applicable during road use (in any layer) is set, it is based on the comparison between the range of LCI and EP and TP indicators (impacts) of alternative resources and of the pavements made with these resources.

\section{Impacts assessment of roads alternative materials}

\subsection{Review of literature}

A state of the art was undertaken in 2001 and updated in 2014 through the French national project OFRIR [19] dealing with back analysis of alternative material use in transport infrastructures. A network of actors of the public organisms involved in the project performed a very wide survey. In 2014, the project included also LCA data dedicated to road applications and a state of the art of LCA for each resource available (http://ofrir2.ifsttar.fr) [6]. Today, after several international conferences on the topic (LCA 2014 [20], LCA 2017 [21]) alternative materials ecotoxicity and toxicity impacts have still to be assessed for use in roads.

Some recent literature standards [22] and review [23] gather and explain the knowledge on LCA applied to construction and road sectors including alternative materials [18]. Mid-points and end-points indicators impacts calculation methods, and available tools and LCI database are considered. The literature highlights that neither excotoxicity nor toxicity impacts are assessed by NF EN 15804 [22]. Only ecotoxicity is mentioned in a 2016 literature review [23]. Besides, for other authors (i.e. [24]), the full set of indi-cators including toxicity and ecotoxicity is taking into considera- tion mi-points indicators but in a very global way. Indeed, as regards road sections, the impact assessment of the release to water should be linked with local data. Therefore, if alternative materials are used they should be related to the precise road works investigated. Such approach would be better than the use of glob-alized data by means a national database containing old historic data. However, this implies to be able to assess quickly and simply any local resource release in a robust way. Hence, the waste from which derives an alternative resource has changing chemical com-position with time, inducing different release to environment and associated impacts.

\subsection{Indicators}

The calculation of impact indicators is performed according to a model explained in a previous work by Sayagh et al. [25]:

Indj $1 / 4 \quad a_{i j} \quad C_{i j} \quad m_{i}$

where Indj = indicator associated with impact category $\mathrm{j}$; $\mathrm{aij}_{\mathrm{ij}}=$ classification coefficient (from Goedkoop, [26]; $\mathrm{C}_{\mathrm{ij}}=$ contribution coefficient of inventory flow $\mathrm{i}$ to impact category $\mathrm{j} ; \mathrm{m}_{\mathrm{i}}=$ mass of inventory flow $\mathrm{i}(\mathrm{kg})$.

Each indicator is expressed in specific units per kilogram or tons. The contribution coefficients selected from the literature and used for the impact calculations, based on Eq. (1), and the cho-sen impact categories (and indicators) are derived from classical LCA and include all references given in [25]. Only ecotoxic poten-tial, EP ( $\mathrm{kg}$ eq 1,4 DCB), and toxic potential, TP (kg Eq 1,4 DCB), are investigated in the present study. The EP and TP values were calculated using ECORCE database [9] which integrates the first work of Huijbregts, updated in 2000 [27].

\subsection{System boundaries}

Performing materials LCA as initiated by SETAC [11] involves underlying objectives leading to compare products (or processes) or providing environmental information (for public and/or private organizations). In the former case, the system includes only pro-cesses and life cycle steps that may induce differences between the compared products. The latter need to choose wide systems. Fig. 1 gives industrial waste second life options investigated here. We focus on recycling options of aggregates and sand for road use, without assessing landfilling option.

Fig. 2 describes the system boundary to build the LCI. The mate-rials selected cover a range of secondary aggregates resources avail-able for roads and address several kinds of road layers and traffics.

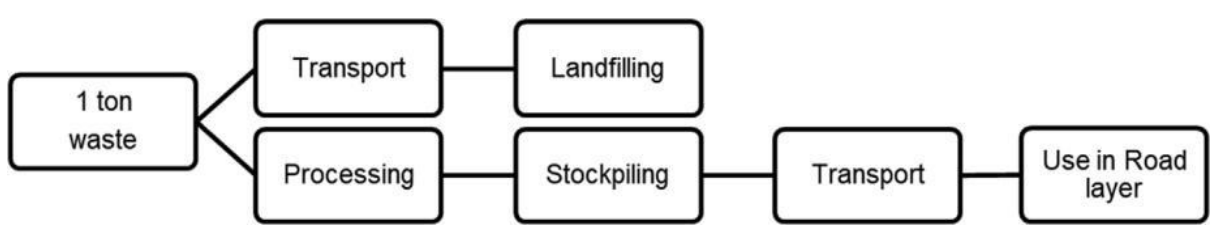

Fig. 1. Industrial waste second life options investigated.

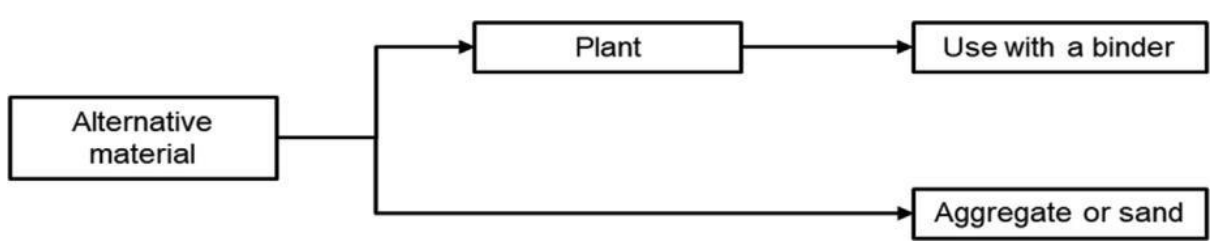

Fig. 2. Alternative material road use studied. 


\subsection{Methodology to build the LCIs to assess release to water}

According to standards, leaching and percolating tests are expressed in concentrations of leaching pollutants. The LCIs in the study were built transforming leaching and percolation results into flux data. This is applicable on any test performed with various international standards.

After building LCI of alternative resources (Section 3.4.1) and building LCI for the case studies (Section 3.4.2), the respective impacts were determined, using the model of impacts calculation presented in Section 2.2. for the studied materials.

The assumption of allocating all the materials leaching potential to their LCI was investigated to take into account release to water during all their life cycle. To validate this assumption, the EP and TP impacts of the materials and pavements were considered.

\section{Materials, roads experimental sections and methods}

Municipal solid waste incineration bottom ash (MSWI BA), reclaimed asphalt pavement (RAP) and foundry sand (FS), and the corresponding leaching data were investigated to assess LCI and impacts.

\subsection{Municipal solid waste incineration bottom ash (MSWI BA)}

Old MSWI BA was obtained from a road section at La Teste near Bordeaux in France after a long period of service. In the area of the road section, important quantities of MSWI BA were sampled on the production site of MSWI BA after the incineration (frequently incomplete) of municipal solid waste in early 2000. Before use, the raw MSWI BA are discharged in wet condition from the furnace chamber. They are transferred to a platform for processing (crush-ing, scrapmetal removal and screening). Then, this resource is stockpiled for months to be aged prior to landfilling or use as sec-ondary aggregates for road construction. Leaching tests according to the NFX31-210 [28] were performed on the MSWI BA studied

[29] at different life stages (raw materials, 6 weeks aging, 5, 6 and 18 months aged samples).

\subsection{Reclaimed asphalt pavement (RAP)}

Reclaimed asphalt pavement studied herein was obtained from a demolition/reconstruction road site located close to the city of Romorantin, on France's RN76 supporting a heavy traffic [30]. The pavement was slowly and selectively milled in 2001, from the existing pavement surface to obtain reclaimed asphalt pave-ment of high quality, suitable grading and for direct recycling in the plant with the new binder (without additional processing on the milled aggregate). This road works included a specific pro-gramme for the environmental impact assessment of pavement construction and use under traffic conditions. New asphalt with recycling rates of $0 \%, 10 \%, 20 \%$ and $30 \%$ of the old pavement was produced. Four road sections $150 \mathrm{~m}$ long and $3.80 \mathrm{~m}$ wide were realised. Road rebuilding was undertaken using hot-mixed asphalt pavement made of either 5\% bitumen and $95 \%$ natural aggregates or a mixture containing natural aggregates and different rates of reclaimed asphalt pavement. Here only the 20\% RAP binding course section is considered.

\subsection{Foundry sands (FS)}

The foundry sand of a secondary road under rehabilitation in 2012 (France RN 80) was studied. More than 17000 tons of waste foundry sands stockpiled at Autun city were treated with hydraulic binder (cement) to constitute the subbase layer with a thickness of $46 \mathrm{~cm}$. Waste foundry sands present a gapgrading analysis close to $0 / 2 \mathrm{~mm}$ with more than $80 \%$ as fines $(<0.5 \mathrm{~mm})$. They are relatively homogenous across the samples. Foundry sand con-sists of primarily of clean, uniformly sized, high-quality silica sand or lake sand that is bonded to form moulds and cores for ferrous (iron and steel) and nonferrous (copper, aluminium, brass) metal castings due to its thermal conductivity. In foundry, the sand is regenerated several times. It is removed and qualified as waste foundry sand (FS) when it cannot be regenerated any more. Then it is tested, analysed and stockpiled for another use. In the RN 80 road section the bituminous wearing course is of $18 \mathrm{~cm}$ thick as follows: $10 \mathrm{~cm}$ of high modulus asphalt (EME), $6 \mathrm{~cm}$ of bituminous concrete with high modulus (BBME) and $2.5 \mathrm{~cm}$ of very thin bitu-minous concrete (BBTM) [13].

\subsection{Materials and pavement LCIs}

LCI is built considering data from leaching and percolation test as shown on Fig. 3. The leaching tests were done on crushed aggre-gates according to NFX31-210 [28]. The test consists of extractions of the material at liquid on solid ratio (L/S) equal to 10 by specific mixing. The leachate is demineralized water and the particle size is inferior to $4 \mathrm{~mm}$.

\subsubsection{Alternative materials LCI from leaching data}

Table 1 gives the LCI for all the studied materials. The pollutant concentrations are obtained using the NF X31210 [28] applicable at this time. Although the NFX31-210 [28], was replaced by the NF EN 12457 [31], the method for LCI determination is still valid. The dis-cussion section shows the influence of the standard. All the data of the present study were obtained considering NFX31-210 [28].

\subsubsection{In situ pavement materials LCI from leaching data}

The leaching data for each experimental road section are detailed below. LCIs are given for each material.

Fig. 4 shows the MSWI BA LCI data and the materials location in the pavements (La Teste road section) after 22 years of service. The

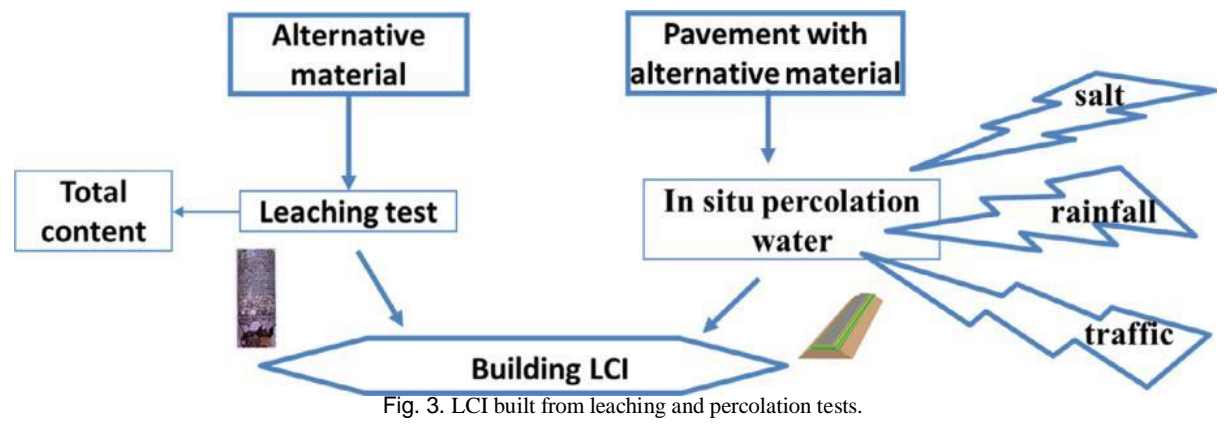


Table 1

LCI results at material scale for MSWI BA, RAP and FS with NF X31210 [28] (-: not determined).

\begin{tabular}{|c|c|c|c|}
\hline $\mathrm{mg} / \mathrm{Kg}$ & $\begin{array}{l}\text { MSWI BA } \\
18 \text { months }\end{array}$ & RAP & FS \\
\hline $\mathrm{Al}$ & 1.4. $10 \quad 3$ & - & - \\
\hline As & - & - & 1.29 \\
\hline $\mathrm{Ba}$ & - & - & 1.09 \\
\hline $\mathrm{Cd}$ & $<3.0 .10 \quad 3$ & - & $<0.05$ \\
\hline $\mathrm{Cr}$ (total) & $<0.9$ & - & $<0.1$ \\
\hline $\mathrm{Co}$ & - & - & $<0.3$ \\
\hline $\mathrm{Cu}$ & 0.9 & $<0.050$ & 0.6 \\
\hline $\mathrm{Fe}$ & $<0.9$ & - & - \\
\hline $\mathrm{Hg}$ & - & - & $<0.002$ \\
\hline Mo & - & - & $<0.3$ \\
\hline $\mathrm{Ni}$ & - & - & $<0.2$ \\
\hline $\mathrm{Pb}$ & $<0.9$ & - & $<0.24$ \\
\hline $\mathrm{Se}$ & - & - & $<0.2$ \\
\hline $\mathrm{Zn}$ & 0.5 & 1.150 & $<1.5$ \\
\hline Chlorides & 2114 & $<50$ & 15.02 \\
\hline Sulfates & 979 & 22 & 47.29 \\
\hline Ammonia nitrogen & - & - & 120.24 \\
\hline Nitrates nitrogen & - & - & 103.3 \\
\hline Total organic carbon & - & 31 & 64.1 \\
\hline Total Cyanide & - & - & 0.6 \\
\hline Phenol & - & - & $<1.5$ \\
\hline
\end{tabular}

layers were made of MWSI BA in this road section and drilling were realized in both (sample A) and (sample B) [32]. Then leaching tests were performed on these drilled materials.

Fig. 5 shows the $20 \%$ RAP LCI data and the RAP position in the RN76 binding course rebuilt and instrumented. The percolated water was periodically sampled on the RN76 site. Released pollu-tants were analysed and quantified. LCI was determined from 2 years cumulated values.

Fig. 6 highlight the LCI data of FS of the instrumented RN80 road section for percolated water collection and chemical analysis. The LCI of the FS use phase corresponds to a 2 years infiltration period.

Because of the implementation of the alternative material with other upper layers and compaction of the upper courses, the water percolation through the pavement layer must be limited with time. Some percolation levels are given in literature as between some $\%$ up to $15 \%$ of infiltration rates. As the purpose of the present study is only to build LCI of alternative materials in relation with leaching pollutants total amount, the conditions of percolation and infiltra-tion volumes are not given. They have been published for FS in [13] and for RAP in [30].

\section{Impacts results \\ 4.1. Impacts assessment of materials with $\mathrm{EP}$ and $\mathrm{TP}$}

Fig. 7a and 7b give the impacts of MSWI BA during the storage on the platform. These leaching tests were performed in 2003 according to [29] after 6 weeks, 5, 6 and 18 months of stockpiling. Each element to EP and TP contribution is highlighted. Indeed the pollutant release is decreasing with time. The corresponding EP and TP value drop more than one order of magnitude. Hence, the variation of EP, TP with time look very sensitive and valuable to assess potential impacts on environment of stockpiling.

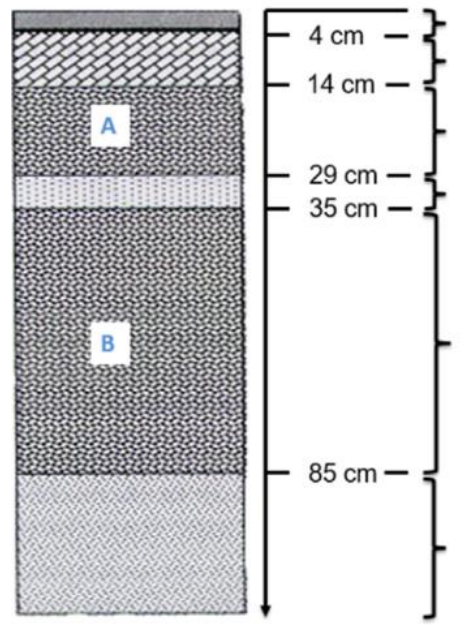

Asphalte concrete

$\mathbf{m g} / \mathbf{k g}$

Sample A Sample B

\begin{tabular}{lcc}
\hline $\mathbf{A l}$ & 15 & 13 \\
\hline $\mathbf{C d}$ & $<0.005$ & $<0.005$ \\
\hline $\mathbf{C r}$ (total) & 0.16 & 0.12 \\
\hline $\mathrm{Cu}$ & 0.8 & 0.6 \\
\hline $\mathbf{F e}$ & 10 & 6 \\
\hline $\mathbf{M n}$ & $<0.33$ & $<0.31$ \\
\hline $\mathbf{N i}$ & $<0.15$ & $<0.18$ \\
\hline $\mathbf{P b}$ & 1.2 & 0.9 \\
\hline $\mathbf{Z n}$ & 2.0 & 3.3 \\
\hline Chlorides & 38 & 35 \\
\hline Sulfates & 423 & 219
\end{tabular}

Fig. 4. Pavement structure of the $320 \mathrm{~m} 7 \mathrm{~m}$ traffic T4 (30-40 heavy vehicles/day) and MSWI BA leaching results with NF X31-210 [27] after 22 years of service.

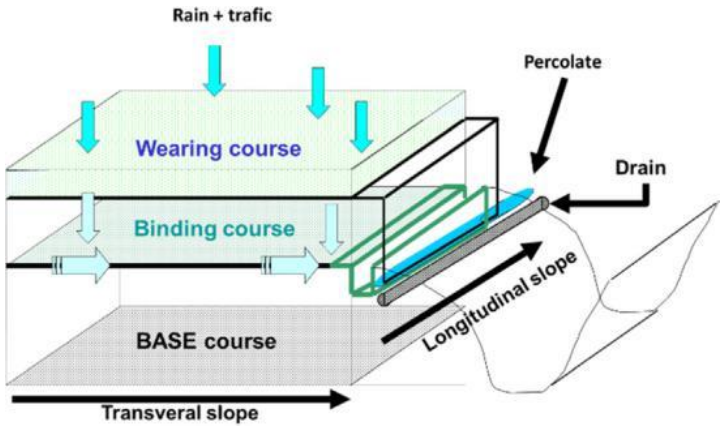

\begin{tabular}{lc|cc}
\hline $\boldsymbol{\mu g} / \mathbf{k g}$ & $\begin{array}{c}\text { Cumulated } \\
\text { content }\end{array}$ & $\boldsymbol{\mu g} / \mathbf{k g}$ & $\begin{array}{c}\text { Cumulated } \\
\text { content }\end{array}$ \\
\hline $\mathbf{C d}$ & 1.1 & $\mathbf{P b}$ & 16.3 \\
\hline $\mathbf{C u}$ & 320 & $\mathbf{Z n}$ & 407 \\
\hline $\mathbf{C r}$ & 19 & $\mathrm{HAP}$ & 0.891 \\
\hline $\mathbf{N i}$ & 23.2 & & \\
\hline
\end{tabular}

Fig. 5. RN 76 pavement structure of the $63.8 \mathrm{~m}$ instrumented section (heavy traffic) and pavement (very thin asphalt BBTM wearing course + medium coarse asphalt BBSG with $20 \%$ RAP binding course) percolation results after 2 years of service [29]. 


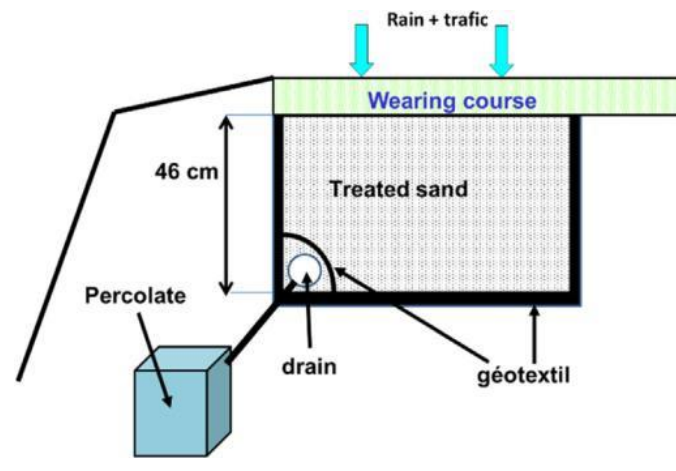

\begin{tabular}{lc|lc}
\hline $\mathbf{m g} / \mathbf{k g}$ & $\begin{array}{c}\text { Cumulated } \\
\text { content }\end{array}$ & $\mathbf{m g} / \mathbf{k g}$ & $\begin{array}{c}\text { Cumulated } \\
\text { content }\end{array}$ \\
\hline $\mathrm{Al}$ & 2.588 & $\mathrm{Ni}$ & 0.079 \\
\hline $\mathrm{Cd}$ & 0.000 & $\mathrm{~Pb}$ & 0.001 \\
\hline $\mathrm{Cr}$ & 0.002 & $\mathrm{Zn}$ & 0.000 \\
\hline $\mathrm{Cu}$ & 0.0081 & Chloride & 9.09 \\
\hline $\mathrm{Fe}$ & 0.000 & Sulphates & 19.82 \\
\hline $\mathrm{Mn}$ & 0.003 & Phenol & 0.057 \\
\hline
\end{tabular}

Fig. 6. RN 80 pavement structure instrumented cross section of $203.5 \mathrm{~m}$ (low traffic) of the experimental site for foundry treated sand section percolation after 2 years of service [13].
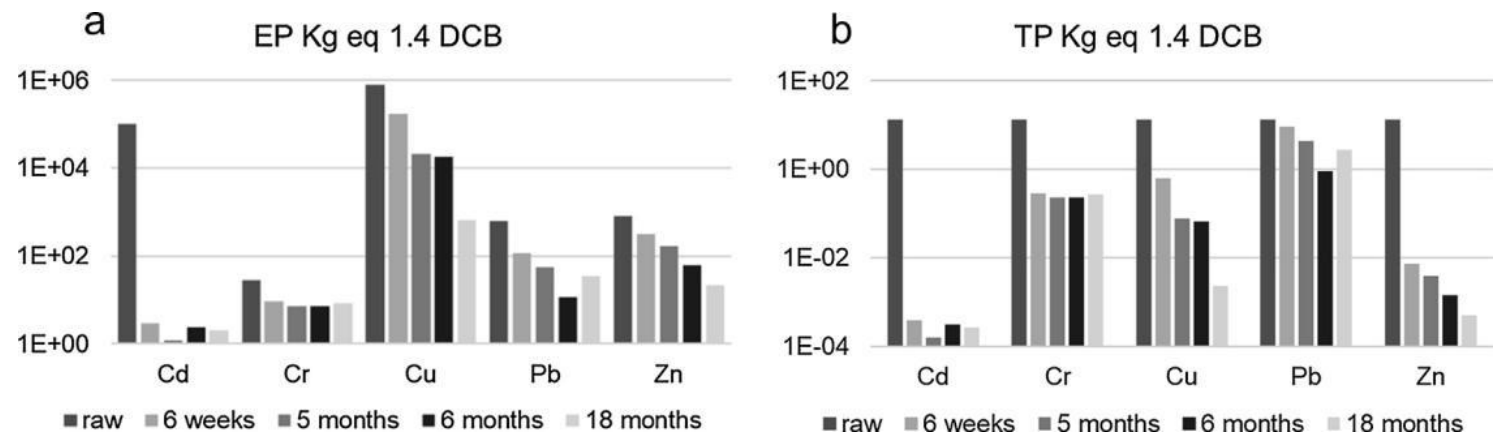

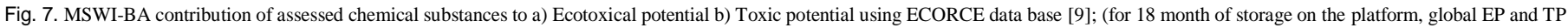
are respectively 703 and 3.02 in kg eq. $1.4 \mathrm{DCB}$ by tons of materials)

Table 2 shows EP and TP and results for the raw alternative materials of the RN76 and RN80 tests sections. Only RAP and FS are considered (from table 1) as their data were obtained before the pavement construction with samples used for each roadwork, while for MSWI BA bottom ash leaching data of the La Teste road section they were not available.

\subsection{In situ impacts assessment with EP and TP}

Table 3 gives the impacts of alternative materials during the use phase. MSWI BA impacts are residual impacts after 22 years of ser-vice corresponding to leaching tests on crushed drilled MSWI BA (see Fig. 4 sample $\mathrm{A}$ and $\mathrm{B}$ ). The pavement layers (sample A and

B) have been submitted to rainfall, with possibly significant perco-lating water rates. RN76 pavement including RAP shows the EP and

Table 2

EP and TP values for RN76 RAP and RN80 FS before use in the pavements by tons of materials.

\begin{tabular}{lll}
\hline & RAP(NF X31210) & FS (NF X31210) \\
\hline EP kg eq. 1.4 DCB & 51.1 & $1.72 .10^{4}$ \\
TP kg éq. 1.4 DCB & $10.1 \mathrm{E} 03$ & 17.6 \\
\hline
\end{tabular}

Table 3

EP and TP values obtained for different road sections by tons of material.

\begin{tabular}{llll}
\hline & $\begin{array}{l}\text { MSWI BA } \\
22 \text { years [31] } \\
\text { Sample A/B }\end{array}$ & $\begin{array}{l}\text { RN76 20\% RAP } \\
{[30]}\end{array}$ & $\begin{array}{l}\text { RN80 FS } \\
{[13]}\end{array}$ \\
\hline EP kg eq. 1.4 DCB & $660 / 574$ & 48.9 & 547 \\
TP kg eq. 1.4 DCB & $0.42 / 0.32$ & 0.027 & 0.0427 \\
\hline
\end{tabular}

TP values lower than for MSWI BA 18 month as expected, whereas foundry sand indicators are much higher in a 2 years period. Both the initial content of materials and percolating ratios could explain the difference.

Tables 3 and 2 results show that for eco-toxicity potential (EP) and toxicity potential (TP), the maximum values are obtained for leaching tests performed on powder. Drop of fuel and oil on the pavement during percolation under traffic can add effects.

\subsection{Allocation of leaching impacts to alternative materials}

The ECORCE model developed in all kinds of road materials was applied for EP and TP assessment for MSWI BA, RAP and FS along their "second" life according to Fig. 2). The range of EP and TP var-ied strongly between the three materials. For all the selected alter-native materials, for which available data were known, calculation gave discriminant impact results: EP ranging from 51 to $1.7 .10^{4} \mathrm{~kg}$ eq. $1.4 \mathrm{DCB}$ by tons of materials and TP ranging from $1.17 .10^{3}$ to $17.6 \mathrm{~kg}$ eq. $1.4 \mathrm{DCB}$ by tons of materials. Such indicators are showing also the ability to assess stockpiling (see Fig. 7, for MSWI BA) and use in various scenario (Table 3 ). Hence, this study shows the sensitivity of indicators like EP and TP to various scenarios with alternative materials. It suggest the necessity to add these impacts to the global life cycle when the alternative materials are used.

The historic data from the three field experiments (Section 3-4-

2) cannot be directly compared because the road sections and traf-fic are not identical. Indeed, the scenario strongly depends on the binders around it, the pavement compaction and the traffic.

However, the trends obtained indicate that in situ percolation is less influencing than the leaching of the resources. For road use 
assessment, in situ percolation on test section gives impacts only on a given period that can roughly be longer than several years. The tests are realised after building the road. The assessment for alternative materials in industrial context cannot be done in such a way for EP and TP.

Our proposal would be to add to the resource LCI, the values obtained from leaching data of raw alternative materials (Table 1). Such an assessment model allocates the maximum potential values of all the life cycle to the resource.

\section{Discussion}

The fact that the impacts of alternative materials are not consid-ered in LCA studies introduces a bias in a global approach, espe-cially comparing with new natural resources. In this context, this study aimed at quantifying such impacts for some case studies.

In this study, significant differences are obtained between MSWI BA, RAP and FS ecotoxicity and toxicity impacts (with the ECORCE model). Such differences are observed both for raw mate-rials and for road use scenario.

Only leaching data are required to apply the method of impacts allocation for a resource level calculations at an international scale. Table 4 highlights a non-exhaustive list of available leaching pollu-tant investigated in literature for various standards and focusing on wider number materials. The requirements to apply such alloca-tion would be to perform leaching tests on crushed raw material determining the major leaching elements to measure. Then, a model is selected for impacts calculation.

These results are consistent with those obtained in [18]. In [18], authors were modelling pollutants release, transport and impact from FS and MSWI BA looking at three scenario of use: a road dam, a parking and a noise protection dam. The model in [18] con-sidered the USEtox method and its endpoint ecotoxicity indicator. However, strongly different values as regards the type of alterna-tive materials were also determined like in the present study (see Fig. 7 and Table 2).

Our proposal is to assess the leaching material impacts of the alternative resources for all their life as if they were those of the use phase in given scenario by allocating LCI to the resource. This methodology is applicable to any resource and to various leaching tests and standards. However, alternative materials composition depends on the production site. They are most of the time local resources with specific chemical content and at least process dependent LCI.

The methodology is still valid for other impact assessment methods because it considers only LCI. As for impact over estima-tion, it depends on the road layer considered. In road section, the layers can last either 10 years for a wearing course but may last longer. This model seems to be more realistic for lower course especially knowing that alternative materials are preferably located in lower layers.

\section{Conclusion}

LCA was performed for leaching assessment of granular alterna-tive materials use in road construction. Dedicated LCIs were built. The potential pollutions was determined by means of leaching tests on resources and by pollution release during percolation field experiments on road sections submitted to traffic. Because pollu-tant release to water depends on the $\mathrm{L} / \mathrm{S}$ ratio with time and of the exchange surfaces between the crushed materials and the water, we considered that leaching potential from granular resource could define an upper limit reached for ecotoxicity and toxicity impacts during the material processing and use phase.

Three alternative materials (MSWI BA, RAP and FS) are stud-ied. Old data and recent data from leaching tests are considered. The EP and TP results exhibited significant differences between the resources (content, processing and use) in favour of including such impact to LCA for recycling assessment. The RAP LCI of this study can be used as general data, while MSWI BA and FS LCIs, which depend on local production site (in France), should be considered as specific data. Because of materials heterogeneity, LCI should be improved by the characterisation of several samples.

Of course, allocating the materials maximum impact values for the whole road life cycle could overestimate real impact. However, doing so would be conservative as regards an engineering approach and more adapted to compare alternative materials with natural materials. LCI implementation in LCA tools is easy for any resources.

Table 4

Application to other materials and leaching test at the international level.

\begin{tabular}{|c|c|c|c|c|c|c|c|c|c|c|c|c|c|c|c|c|c|c|}
\hline & & \multicolumn{2}{|l|}{ Test } & \multicolumn{4}{|l|}{ Sample } & $\mathrm{Ag}$ & $\mathrm{Al}$ & As & & $\mathrm{Cd}$ & $\mathrm{Co}$ & $\mathrm{Cr}$ & $\mathrm{Cu}$ & $\mathrm{Fe}$ & $\mathrm{Hg}$ & $\mathrm{Mn}$ \\
\hline Engelsen [33] & \multicolumn{3}{|c|}{$\mathrm{L} / \mathrm{S}=10$} & \multicolumn{3}{|c|}{ Concrete aggregates } & $\mathrm{mg} / \mathrm{kg}$ & & & & & $\mathrm{X}$ & & $\mathrm{X}$ & $\mathrm{X}$ & & & $X$ \\
\hline Galvin [34] & \multicolumn{3}{|c|}{ EN 12457-3 } & \multicolumn{3}{|c|}{ Demolition waste } & $\mathrm{mg} / \mathrm{kg}$ & & & $\mathrm{X}$ & & $\mathrm{X}$ & & $\mathrm{X}$ & $\mathrm{X}$ & & $\mathrm{X}$ & \\
\hline Leiva [35] & \multicolumn{3}{|c|}{ EN 12457-4 } & \multicolumn{3}{|c|}{ Concrete aggredates } & $\mathrm{g} / 1$ & & & $\mathrm{X}$ & & $\mathrm{X}$ & & $\mathrm{X}$ & $\mathrm{X}$ & & & \\
\hline Marion [36] & \multicolumn{3}{|c|}{ NEN 7343} & \multicolumn{3}{|c|}{ Concrete aggegates } & $\mathrm{mg} / \mathrm{kg}$ & $\mathrm{X}$ & & $\mathrm{X}$ & & $\mathrm{X}$ & & $\mathrm{X}$ & $\mathrm{X}$ & & $\mathrm{X}$ & $\mathrm{X}$ \\
\hline Meve Basar [37] & \multicolumn{3}{|c|}{ EN 12457-4 } & \multicolumn{3}{|c|}{ WFS } & $\mathrm{mg} / \mathrm{l}$ & & & & & & & $\mathrm{X}$ & & & & \\
\hline Mroueh, 2001 [38] & \multicolumn{3}{|c|}{ EN 12457} & \multicolumn{3}{|c|}{ Natural aggregates } & $\mathrm{mg} / \mathrm{kg}$ & & & $\mathrm{X}$ & & $\mathrm{X}$ & & $\mathrm{X}$ & & & & $\mathrm{X}$ \\
\hline Roussat [39] & \multicolumn{3}{|c|}{ TS14405 } & \multicolumn{3}{|c|}{ Demolition waste } & $\mathrm{mg} / \mathrm{l}$ & & & $\mathrm{X}$ & & $\mathrm{X}$ & $\mathrm{X}$ & $\mathrm{X}$ & $\mathrm{X}$ & & $X$ & \\
\hline Sorlini $[40]$ & \multicolumn{3}{|c|}{ EN 12457} & \multicolumn{3}{|c|}{ Waste /natural aggregates } & $\mathrm{mg} / \mathrm{kg}$ & & & & & & & $\mathrm{X}$ & $\mathrm{X}$ & & & \\
\hline Siddique [41], Deng [42] & & & & \multicolumn{3}{|c|}{ Sand dust } & $\mathrm{mg} / \mathrm{l}$ & $\mathrm{X}$ & $\mathrm{X}$ & $\mathrm{X}$ & & $\mathrm{X}$ & & $\mathrm{X}$ & $\mathrm{X}$ & $\mathrm{X}$ & $X$ & $\mathrm{X}$ \\
\hline Siddique [41], Ji [43] & & & & \multicolumn{3}{|c|}{ Foundry sand } & $\mathrm{mg} / \mathrm{l}$ & $\mathrm{X}$ & & $\mathrm{X}$ & & $\mathrm{X}$ & & $\mathrm{X}$ & $\mathrm{X}$ & & $\mathrm{X}$ & \\
\hline Wahlkstrom [44] & \multicolumn{3}{|c|}{ EN 12457 et NEN 7343} & \multicolumn{2}{|c|}{ Demollition waste } & & $\mathrm{mg} / \mathrm{kg}$ & & $\mathrm{X}$ & & & $\mathrm{X}$ & & $\mathrm{X}$ & & & & \\
\hline & Mo & $\mathrm{Ni}$ & $\mathrm{Pb}$ & $\mathrm{Sb}$ & $\mathrm{Se}$ & $\mathrm{V}$ & $\mathrm{Zn}$ & & $\mathrm{Ba}$ & & $\mathrm{Na}$ & & $\mathrm{Cl}_{-}$ & & $\mathrm{F}$ & $\mathrm{NO}_{3}$ & & $\mathrm{SO}_{4}$ \\
\hline Engelsen [33] & $\mathrm{X}$ & $\mathrm{X}$ & $\mathrm{X}$ & & & $\mathrm{X}$ & $\mathrm{X}$ & & & & & & & & & & & \\
\hline Galvin [34] & $\mathrm{X}$ & $\mathrm{X}$ & $\mathrm{X}$ & $\mathrm{X}$ & $\mathrm{X}$ & & $\mathrm{X}$ & & $\mathrm{X}$ & & & & & & & & & \\
\hline Leiva [35] & & $\mathrm{X}$ & $\mathrm{X}$ & & & & $\mathrm{X}$ & & & & & & & & & & & \\
\hline Marion [36] & & $\mathrm{X}$ & $\mathrm{X}$ & $\mathrm{X}$ & $\mathrm{X}$ & & $\mathrm{X}$ & & $\mathrm{X}$ & & & & & & & & & \\
\hline Meve Basa [37] & & $\mathrm{X}$ & & & & & $\mathrm{X}$ & & & & & & & & $\mathrm{X}$ & & & \\
\hline Mroueh [38] & $\mathrm{X}$ & $\mathrm{X}$ & $\mathrm{X}$ & & & $\mathrm{X}$ & $\mathrm{X}$ & & & & & & & & & & & \\
\hline Roussat [39] & $\mathrm{X}$ & $\mathrm{X}$ & $\mathrm{X}$ & $\mathrm{X}$ & $\mathrm{X}$ & & $\mathrm{X}$ & & & & & & $\mathrm{X}$ & & $\mathrm{X}$ & & & $\mathrm{X}$ \\
\hline Sorlini [40] & $\mathrm{X}$ & $\mathrm{X}$ & $\mathrm{X}$ & $\mathrm{X}$ & & & $\mathrm{X}$ & & $\mathrm{X}$ & & & & $\mathrm{X}$ & & $X$ & $X$ & & $\mathrm{X}$ \\
\hline Deng [42] & & $\mathrm{X}$ & $\mathrm{X}$ & & $\mathrm{X}$ & & $\mathrm{X}$ & & $\mathrm{X}$ & & $X$ & & & & & & & \\
\hline JI [43] & & & $\mathrm{X}$ & & $\mathrm{X}$ & & $\mathrm{X}$ & & $\mathrm{X}$ & & & & & & & & & \\
\hline Wahlkstrom [44] & $\mathrm{X}$ & & $\mathrm{X}$ & & & $\mathrm{X}$ & $\mathrm{X}$ & & & & & & & & & & & $\mathrm{X}$ \\
\hline
\end{tabular}




\section{Declaration of Competing Interest}

The authors declare that they have no known competing finan-cial interests or personal relationships that could have appeared to influence the work reported in this paper.

\section{References}

[1] T. Eighmy, W. Chesner. User guidelines for by products and secondary use materials in pavement construction. Federal highway administration R\&D Center. 2000. (FHWA-RD148). The document is available on http://www. rmrc.unh.edu.

[2] M.J. Simon, W. Chesner, T. Eighmy, H. Jongedyk, National Research Projects on Recycling in Highway Construction. Vol. 64. nL1, United States department of transportation. Federal highway administration, 2006.

[3] A. Jullien, F. De Larrard, M. Bercivici, L. Lumiere, P. Paintone, J. Domas, et al., The Ofrir project: a multi actor approch to recycling in a road infracstructure, Bulletin des Laboratoires des Ponts et Chaussées 275 (2009) 65-84.

[4] L. Château, Environmental acceptability of beneficial use of waste as construction material: State of knowledge, current practices and future developments in Europe and in France, J. Hazard. Mater. B139 (2007) 556-562.

[5] Ofrir. Observatoire Français du Recyclage dans les Infrastructures Routières, 2010, http://ofrir2.ifstarr.fr, [accessed 6-08-2018]

[6] Federal Ministry of the Environment (BMUB). Arbeitsentwurf zur Verordnung zur Festlegung von Anforderungen für das Einbringen oder das Einleiten von Stoffen in das Grundwasser, an den Einbau von Ersatzstoffen und für die Verwendung von Boden und bodenähnlichem Material (Ordinance on Groundwater Protection, Mineral Waste Utilization and Federal Soil Protection and Contaminated Sites, draft mutual release), 2013.

[7] SETRA, French Environmental legislation. Acceptabilité de matériaux alternatifs en technique routière, évaluation environnementale. Ed. Sétra 2011, pp. 28.

[8] M.I. Giani, G. Dotelli, N. Brandini, L. Zampori, Comparative life cycle assessment of asphalt pavements using reclaimed asphalt, warm mix technology and cold in-place recycling, Resour. Conserv. Recycl. 104 (2015) 224-238.

[9] A. Julien, M. Dauvergne, C. Proust, Road LCA: the dedicated ECORCE tool and database, Int. J. Life Cycle Assess. 5 (2015) 655-670.

[10] J. Dos Santos, Pavement LCA, a comparison of American and European tools, LCA 2017 conference,12th april 2017, Champaign, Illinois, USA (http:// lcasymposium.ict.illinois.edu/conference-presentations/)

[11] SETAC, Guidelines for Life-Cycle Assessment: a "code of practice", Ed. SETAC Foundation for Environmental Education, Florida, 1993.

[12] ISO 14040 Environmental management - Life cycle assessment - Principles and framework, in: I.O.f. Standardization (Ed.), 33-46, 2006

[13] O. Yazoghli-Marzouk, N. Vulcano-greullet, L. Cantegrit, L. Friteyre, A. Jullien, Recycling foundry sand in road construction-field assessment, Constr. Build. Mater. 61 (2014) 69-78.

[14] C. Proust, O. Yazoghli-Marzouk, C. Ropert, A. Jullien, LCA of roards alternative materials in various reuse scenarios, International Symposium on Pavement Life Cycle Assessment, October 14-16, 2014, Davis, California, USA

[15] U.-M. Mroueh, P. Eskola, J. Laine-Ylioki, Life-cycle impacts of the use of industrial byproducts in road and earth construction, Waste Manage. 21 (3) (2001) 271-277, https://doi.org/10.1016/S0956-053X(00)00100-8.

[16] S. Olsson. Environmental assessment of municipal solid waste incinerator bottom ash in road construction, September 2005, 34 pages. TRITA-LWR.LIC 2030; ISSN 1650-8629; ISRN KTH/LWR/LIC 2030-SE; ISBN 91-7178-151-X.

[17] Birgisdòttir Harpa, Life cycle Assessment for Road Construction and Use of Residues from Waste Incinerator $\mathrm{PhD}$ Thesis, Institute of Environment and Resources, Technical University of Denmark, 2005, p. 60.

[18] Schwab et al., beyond the material grave: life cycle impact assessment of leaching from secondary materials in road and earth constructions, Waste Mange. (2014) 1884-1896.

[19] A. Jullien, V. Gaudefroy, A. Ventura, R. Paranhos, C. De La Roche, P. Monéron, Airborne emissions assessment of hot asphalt mixing : methods and limitations, Road Mater. Pavement Design 11 (1) (2010) 149-169.

[20] Pavement LCA Symposium, October 14-16, 2014, Davis, California, USA, (http://ucpr.ucdavis.edu/LCA2014).

[21] Life cycle assessment symposium, April 12-13, 2017, Champaign, Illinois, USA, (http://lcasymposium.ict.illinois.edu/)

[22] French standard NF EN 15804 + A1, Sustainability of construction works - environmental product declaration - Core rules for the product category of construction products, Paris 2014.
[23] D.R. Viera, L.J. Calmon, F.Z. Coelho, Life cycle assessment applied to te manufacturing of common and ecological concrete: a review, Construct. Build. Mater. 124 (2016) 656-666.

[24] C. Jiménez, M. Barra, A. Josa, S. Valls, LCA of recycled and conventional concretes designed using the equivalent mortar volume and classic methods, Construct. Build. Mater. 84 (2015) 245-252.

[25] S. Sayagh, A. Ventura, T. Hoang, D. François, A. Jullien, Sensitivity of the LCA allocation procedure for BFS recycled into pavement structures, Resour. Conserv. Recycl. 54 (6) (2010) 348-358, https://doi.org/10.1016/j. resconrec.2009.08.011.

[26] M. Goedkoop, R. Spriensma, The Eco-indicator 99, a damage oriented method for Life Cycle Impact Assessment, methodology report, Pré Consultants B.V. 132 (2001).

[27] M.A.J. Huijbregts, U. Thissen, J.B. Guinée, T. Jager, D. Kalf, D. Van de Meent, Priority assessment of toxic substances in life cycle assessment. Part I. Calculation of toxicity potentials for 181 substances with the nested multimedia fate exposure and effects model USES-LCA, Chemosphere 41 (2000) 541-573.

[28] French standard NF X 31-210: Waste. Leaching test. AFNOR. France, Paris; 1998.

[29] D. François, Relargage en métaux des MIOM à différents stades de leur filière de valorisation, Techniques Sciences et Méthodes. 4 (2003) 91-98.

[30] A. Jullien, P. Monéron, A. Ventura, M. Legret, D. Demare, C. De la Roche, M. Schemid, C. Lachet, D. Gaillard, J. Oudin, J.-P. Jacques, B. Meriel, R. Boittin, H. Cabannes, Ph. Jumontier, S. Seytre, K. Lacoste, L. Wendling, M. Bernard, Analyse de Cycle de Vie appliquée à un chantier d'entretien routier sur la RN 76 - Evaluation technique et environnementale d'une couche de liaison d'enrobé bitumineux pour différents taux de recyclage, Ed : LCPC collection ERLPC 225 (2005) pages.

[31] French standard NF EN 12457-2. Characterization of waste - Leaching - Compliance test for leaching of granular waste materials and sludges - Part 2: one stage batch test at a liquid to solid ratio of $10 \mathrm{l} / \mathrm{kg}$ for materials with particle size below $4 \mathrm{~mm}$ (without or with size reduction). AFNOR. France, Paris ; 2002.

[32] D. Francois, M. Legret, D. Damare, P. Fraquet, P. Berga, Comportement mécanique et environnemental de deux chaussées anciennes réalisées avec des mâchefers d'incinération d'ordures ménagères, Bulletin des laboratoires des ponts et chaussées 227 (2000) P15.

[33] C.J. Engelsen, H.A. Van der Sloot, G. Wibetoe, H. Justnes, W. Lund, E. StoltenbergHansson, Leaching characterisation and geochemical modelling of minor and trace elements released from recycles concrete aggregates, Cements Concr. Res. 40 (2010) 16391649.

[34] A. Galvin, J. Ayuso, J.R. Jimenez, F. Agrela, Comparison of batch leaching tests and influence of $\mathrm{pH}$ on the release of metals from construction and demolition wastes, Waste Manage. 32 (2012) 88-95.

[35] C. Leiva, J. Solis-Guzman, M. Marrero, C. Garcia Arenas, Recycled block with improved sound and fire insulation containing construction and demolition waste, Waste Manage. 33 (2013) 663-671.

[36] A.M. Marion, M. De Lanève, A. De Graw, Study of the leaching behaviour of paving concretes: qualification of heavy metal content in leachates issued from tank using demineralized water, Cements Concr. Res. 35 (2005) 951-957.

[37] H. Meve Basar, N.D. Aksoy, The effect of waste foundry sand (WFS) as partial replacement of sand on the mechanical, leaching and micro-structural characteristics of ready-mixed $\begin{array}{lllll}\text { concrete, Constr. } & \text { Build. } & \text { Mater. } 35 & \text { (2012) } & \end{array}$ https://doi.org/10.1016/j.conbuildmat.2012.04.078

[38] U.-M. Mroueh, M. Wahlström, By-products and recycled materials in earth construction in Finland - an assessment of applicability, Resour. Conserv. Recycl. 25 (1-2) (2001) 117129.

[39] N. Roussat, J. Méhu, M. Abdejghafour, P. Brula, Leaching behaviour of hazardous demolition waste, Waste Manage. 28 (2008) 2032-2040.

[40] S. Sorlini, A. Abba, C. Colivignarelli, Recovery of MSWI and soil washing residues as concrete aggregates, Waste Manage. 31 (2011) 289-297.

[41] R. Siddique, G. Kaur, A. Rajor, Waste foundry sand and its leachate characteristics, Resour. Conserv. Recycl. 54 (2010) 1027-1036.

[42] A. Deng, Contaminants in waste foundry sand and its leachate, Int. J. Environ. Pollut. (2009), https://doi.org/10.1504/IJEP.2009.027274.

[43] S. Ji, I. Wan, Z. Fan, The toxic compound and leaching characteristics of spend foundry sands, Water Air Soil Pollut. 132 (2001) 347-364.

[44] M. Wahlkstrom, J. Laine- Ylioki, A. Maattanen, T. Luotojarvi, L. Kivekas, Environmental quality assurance system for use of crushed mineral demolition wastes in road constructions, Waste Manage. 20 (2000) 225-232. 